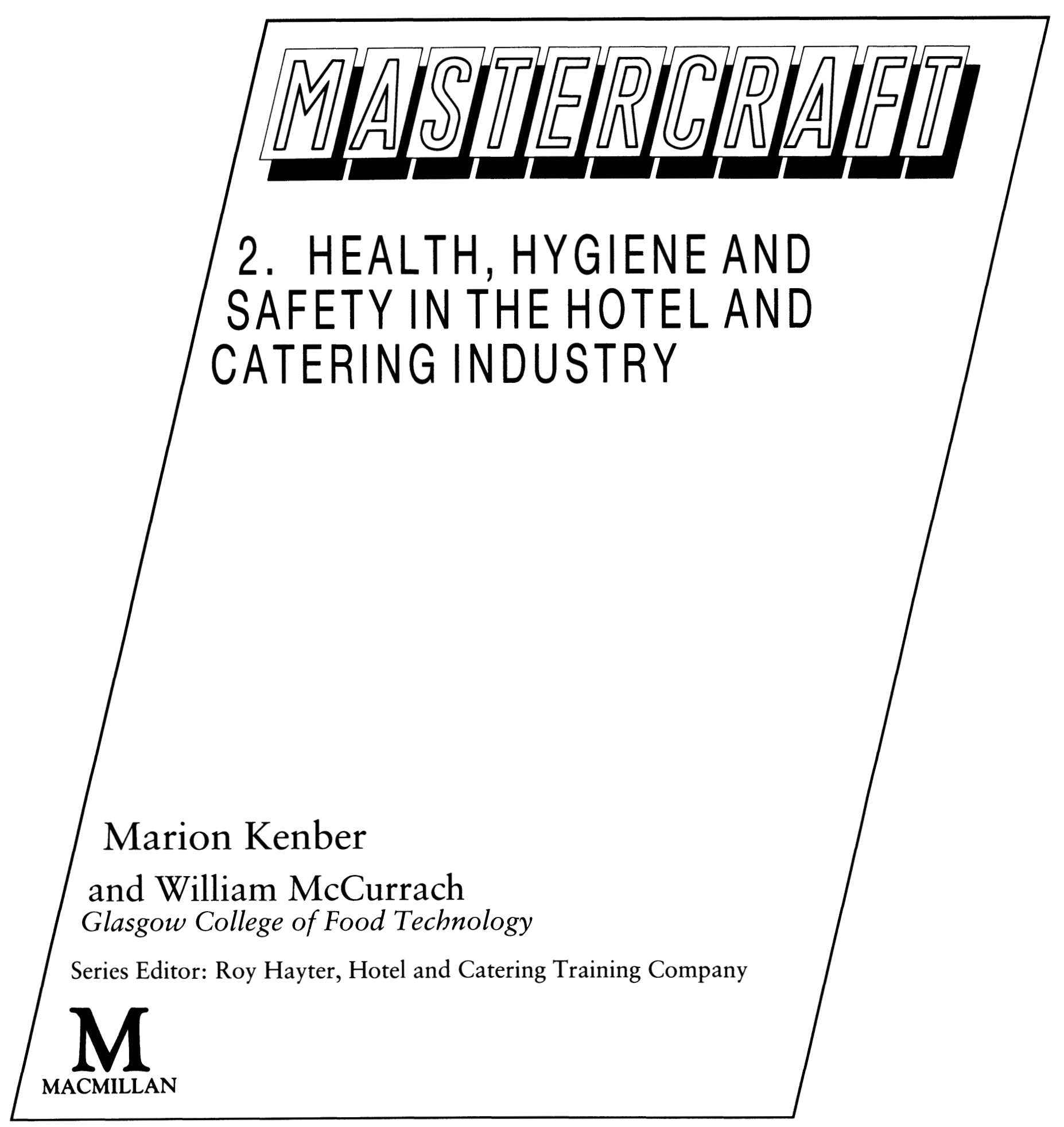


(C) Hotel and Catering Training Company 1990

All rights reserved. No reproduction, copy or transmission of this publication may be made without written permission.

No paragraph of this publication may be reproduced, copied or transmitted save with written permission or in accordance with the provisions of the Copyright, Designs and Patents Act 1988, or under the terms of any licence permitting limited copying issued by the Copyright Licensing Agency, 33-4 Alfred Place, London WC1E 7DP.

Any person who does any unauthorised act in relation to this publication may be liable to criminal prosecution and civil claims for damages.

First published 1990

Reprinted 1990

Published by

MACMILLAN EDUCATION LTD

Houndmills, Basingstoke, Hampshire RG21 2XS

and London

Companies and representatives

throughout the world

British Library Cataloguing in Publication Data

Kenber, Marion

Health, hygiene and safety in the hotel and catering industry.-(MASTERCRAFT; 2).

1. Great Britain. Hotel \& catering industries.

Industrial health \& industrial safety

I. Title II. McCurrach, William III. Series

363.1'1964794'0941

ISBN 978-0-333-45789-4 ISBN 978-1-349-09986-3 (eBook)

DOI 10.1007/978-1-349-09986-3 
Acknowledgements

vi

About this book

\section{The customer}

1 In the hotel and catering industry

\section{Insight}

2 Safety

4

3 Hygiene

6

The impression you give

4 Personal hygiene $\quad 8$

5 Your appearance 10

6 Care of your clothes $\quad 12$

$\begin{array}{ll}7 \text { Working efficiently } & 14\end{array}$

\section{Your health}

8 A healthy diet 16

9 Watch out for $1 \quad 18$

10 Watch out for $2 \quad 20$

11 Keeping fit 22

\section{The law}

12 On health and safety $1 \quad 24$

13 On health and safety $2 \quad 26$

14 On health and safety $3 \quad 28$

15 On health and safety $4 \quad 30$

16 On food (and drink) hygiene 1

17 On food (and drink) hygiene 2 34 
Fire

18 Fire prevention 36

19 Staff training in fire 38

20 Fire fighting $1 \quad 40$

21 Fire fighting 2

22 Evacuation procedures 44

\section{Security}

23 Security procedures 1

24 Security procedures $2 \quad 48$

25 Security procedures $3 \quad 50$

26 Security procedures 4

27 Keys $\quad 54$

\section{Health, hygiene and safety}

28 Preventing accidents 1

29 Preventing accidents $2 \quad 58$

30 Preventing accidents $3 \quad 60$

31 Cleaning procedures $1 \quad 62$

32 Cleaning procedures 2

33 Cleaning agents 66

34 Pest control $1 \quad 68$

35 Pest control 2 70

36 Waste disposal 72

37 In food preparation 1

38 In food preparation 2 76

39 In food preparation $3 \quad 78$

40 In food preparation $4 \quad 80$

41 In food preparation $5 \quad 82$

42 In food preparation $6 \quad 84$

43 In food service $\quad 86$

44 At the bar $\quad 88$ 
45 In housekeeping 90

46 In front of house $\quad 92$

47 In the catering stores and cellar $\quad 94$

48 In leisure areas $1 \quad 96$

49 In leisure areas $2 \quad 98$

\section{First aid}

50 First on the scene 100

51 Finding out what's wrong 1 102

52 Finding out what's wrong 2

53 Finding out what's wrong $3 \quad 106$

54 Resuscitation $1 \quad 108$

55 Resuscitation $2 \quad 110$

56 How to control bleeding 112

57 Shock, heart attacks and strokes $\quad 114$

58 Burns and scalds 116

59 Fractures 118

60 Dressings and bandages 120

Index 
Macmillan Education and the Hotel and Catering Training Company are grateful to Mary James and Melvyn Teare who were responsible for setting up the original structure and scope of this book, to Gillian Wright who commented on the draft text, to Jennifer Kimber who helped edit the text, to Jennifer Murray who also helped edit the text and who briefed and organised the photographic sessions with Catherine Blackie.

The publishers would also like to express sincere thanks to the following for their help in supplying photographs and illustrations:

Allibert Leisure Furniture, Cowes (units 31 and 49)

Beefeater Steak House, Surbiton (units 6, 16, 37 and 44)

Catherine Blackie (picture research, photographs in units 3 and 20, and at

Beefeater Steak House, Flemings Hotel, Granada Motorway Services, Inn on the

Park and Princess Louise)

Burford Bridge Hotel (Trusthouse Forte), Box Hill, Dorking (cover, photographer Transmedia)

W M Christy \& Co (unit 26)

Copthorne Hotels (unit 46, The Copthorne, Plymouth and unit 48, The Copthorne, Birmingham)

Crest Hotels Ltd (units 3 and 15)

The Electricity Council, London (line illustrations in units 36 and 42)

Evening Argus, Brighton (unit 2)

Flemings Hotel, Mayfair, London (units 4, 5, 7, 14, 20, 24, 27, 29, 32, 43, 45 and

46)

Fire Protection Association (unit 19, photographer Douglas C. Morris \& Co.)

Fire Protection Services, Birmingham (unit 21)

Format Photographers Ltd (units 10 and 31, photographer Jenny Matthews; unit 12, photographer Michael Ann Mullen; unit 30, photographer Maggie Murray; units 9, 11 and 28, photographer Brenda Prince and unit 32, photographer Joanne O'Brien)

The Fresh Fruit and Vegetable Information Bureau, London (unit 9)

Gardner Merchant Ltd, Manchester (unit 37)

Granada Motorway Services Ltd, Heston Services M4 (units 25, 42, and 43)

Sally and Richard Greenhill, Photographers Photo Library (units 7, 10, 11, 14 and 24)

Guidepost Hotel, Bradford (unit 40, photographer Robin Matthams)

The Inn on the Park, London (units 15, 19, 28, 38, 39, 40 and 47)

Little Chef (units 6 and 12)

London Tara Hotel (unit 17, photographer Catherine Blackie, units 3, 6, 23, 29, 32,33 and 36, photographer Alexia Cross)

Novotel, Hammersmith, London (unit 12, photographer Picture Link)

The Press Association Ltd, London (unit 18)

The Princess Louise, Holborn, London (units 22, 23, 28, 32 and 41)

Rentokil Environmental Services Division (units 34 and 35)

Rex Features Ltd (units 1, 2 and 20)

The Royal Marsden Hospital (units 28 and 32, photographer Alexia Cross)

The Savoy Hotel, Strand, London (unit 3)

Science Photo Library (unit 35, photographer Dr Tony Brain)

Rob Shone, London (line illustrations in units 5, 12, 14, 18, 21, 29, 30 and 37)

David Spears Ltd, Stevenage (units 38 and 39)

St John Ambulance, St Andrew's Ambulance Association and The British Red 


\section{ACKNOWLEDGEMENTS}

Cross Society (for permission to adapt the illustrations in units 51, 52, 54, 55, 56, 59 and 60 from First Aid Manual, Dorling Kindersley Ltd, London, 1988). The text in units 50 to 60 is also based on the same source

Stocksigns Ltd, Redhill (unit 15)

Thistle Hotels Ltd (unit 26, The Lowndes Thistle)

Thorn Security Ltd, Oldham (unit 21)

\section{Publisher's note}

While every effort has been made to ensure that the information is correct, Health, Hygiene and Safety in the Hotel and Catering Industry should not be regarded as a complete or authoritative statement of the law. Readers are urged to seek appropriate guidance when they are in any doubt, and will need to note changes in legislation after June 1989. 
More than 4000 accidents to customers and staff in the hotel and catering industry are reported every year in the UK. In particular, the number of cases of food poisoning rose sharply during the 1980s and continues to increase.

Health, hygiene and safety is a part of almost every task, whether it is preparing or serving food, keeping the premises clean, or simply moving from one task to the next. Everyone, not just the management, but the staff as well, has a responsibility to do all they can to protect themselves, the people they work with, and their customers.

\section{The structure of the book}

The book is divided into 60 self-contained units, grouped into nine major subject areas.

The customer - this unit looks at the customer's viewpoint, for without customers there would be no hotel and catering jobs.

Insight - these two units explore the main issues of safety and hygiene in the hotel and catering industry.

The impression you give-how everyone working in hotels, catering, leisure and tourism can make a positive contribution to their workplace, their customers and their colleagues.

Your health-keeping healthy and fit.

The law-a comprehensive summary of the legislation on health, safety and hygiene.

Fire-what causes fires, how they can be prevented, fire fighting techniques and evacuation procedures.

Security-procedures which will help protect the workplace, the property and well-being of customers, staff and owners.

Health, hygiene and safety - the major section of this book. The first nine units cover the aspects that are relevant to all hotel and catering work. A further 13 units deal with specific work areas including food preparation, food service, barwork, housekeeping, front of house, stores and leisure.

First aid - an introduction to first aid procedures designed to encourage and support practical training under the supervision of a qualified first-aider.

Each unit has a TO DO, an activity designed to encourage interest, to help the reader apply the information to his or her own experience and to develop a deeper understanding of the subject.

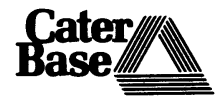

The information in this book will help the reader gain the following Caterbase introductory modules:

- Personal Presentation and Personal Hygiene units 4 to 11

- Safe Working units 2,12 to 15,18 to 22 and 28 to 49

- Hygiene Practices units $3,4,16,17$ and 31 to 49

- Efficient Working units 7, 37 to 49 (see also Mastercraft 1: Working in the Hotel and Catering Industry)

- Emergency Aid at Work units 50 to 60 . 